\title{
Teachers' Pedagogical Skills and Students' Learning of English Language in Oruk Anam Local Government Area of Akwa Ibom State, Nigeria
}

\author{
PRINCEWILL I. EGWUASI, NNENNA F. NNODI and ANIEFIOK S. UDOATAI
}

\begin{abstract}
An investigation into teachers' pedagogical skills and students' learning of English Language in public secondary schools in Oruk Anam Local Government Area of Akwa Ibom State was carried out. Three major variables namely; teachers' classroom management skill, teachers' lesson delivery skill, and teachers' level of communication, were studied to show how it relates with students' learning of English Language. Three research questions and three research hypotheses were raised. The research adopted a descriptive survey approach using a researchers' designed questionnaire titled teachers' Pedagogical Skills and Students' Learning of English Language Questionnaire (TPSSLELQ) with reliability coefficient of 0.857 to collect data from 130 respondents from 10 secondary schools in Oruk Anam Local Government Area of Akwa Ibom State. Pearson Product Moment Correlation (PPMC) was used to test all the hypotheses at 0.05 level of significance. The result of the study revealed that teachers' classroom management skill, teachers' lesson delivery skills, and teachers' level of communication, have a significant relationship on students' learning of English Language. The study recommended among others that teachers should evaluate their lessons at every point as it provides feedback so that students' misconceptions may be clarified. Also, educational stakeholders should take the training and retraining of teachers seriously to boast their competence and managerial skills as it is shown to have a positive relationship on students' learning of English Language.
\end{abstract}

Key words: Teacher, Pedagogical Skills, Learning and English Language

Good and qualified teachers are essential for efficient functioning of educational systems and for enhancing the quality of learning. Teachers have a fundamental role in their learners' academic achievement and their pedagogical effectiveness can have a profound influence on students' outcomes. English Language teachers are by no means an exception and their key role in effective language learning cannot be overlooked. Special attention must be paid to this link between teachers and learners in countries like Nigeria, where language learning happens mainly in formal classroom settings (Kariminia \& Salehizadeh, 2010), and teachers, as the main source of language input to students, affect their learning directly.

Teaching skills involve activities that evoke changes in the learner. Watkins and Mortimore (2011) defined teaching skills as any conscious activity by one person designed to enhance learning in another. This is a sustained process whereby a person acquires new forms or develops existing forms of conduct, knowledge, practice and criteria from somebody or something deemed to be an appropriate provider and evaluator (Bernstein, 2011). This comprises teachers' ideas, beliefs, attitudes, knowledge and understanding about the curriculum, the teaching and learning process and their students. Pedagogy 
is the practice of teaching framed and informed by a shared and structured body of knowledge (Ben, 2013). This knowledge comprises experience, evidence, understanding moral purpose and shared transparent values. It is by virtue of progressively acquiring such knowledge and mastering the expertise through initial training, continuing development, reflection and classroom inquiry and regulated practice that teachers are entitled to be treated as professionals. Pedagogic expertise can be thought of as a combination of science, craft and art (Ben, 2013).

A teachers' knowledge of good pedagogical techniques translates in no small measure to the total achievement of the learners. For this study, the following variables are specifically considered as correlates of pedagogical effectiveness of the teacher. These are: Teachers' professional competence, classroom management skills and teachers' personal characteristics.

The term competence is the ability of an individual to do a job properly. Teachers' professional competence includes the knowledge of his school subject, methodological skills, diagnostic skills, knowledge of the psychology, ability to motivate, self-reflection skills as well as class management skills (Haywood, 2014). Teachers can constantly improve personal competence by reflecting, analyzing the work and looking for further education possibilities. Teachers should be able to promote the academic and social learning of all learners as well as possess knowledge of effective teaching approaches in heterogeneous classes. Good teachers are teachers of all learners (Florian \& Rouse, 2011). Teachers must accept responsibility for facilitating the learning of all learners.

A competent teacher with good pedagogical knowledge can break down difficult concepts into less polished and abstract forms, thus making it accessible to students who are at different cognitive levels. This teacher can unpack the subject into its discrete elements and can explain a concept or procedure at a level that includes the steps necessary for the students to make sense of the reasoning. Competent teachers with good pedagogical knowledge understand where students may have trouble learning the subject and are able to represent the concepts in a way that their students can comprehend its structure and avoid the difficulties.

The most effective teachers have deep knowledge of the subjects they teach, and when teachers' knowledge falls below a certain level, it is a significant impediment to students' learning. As well as a strong understanding of the material being taught, teachers must also understand the ways students think about the content, be able to evaluate the thinking behind students' own methods, and identify students' common misconceptions.

Classroom management is defined as a collection of non-instructional classroom procedures implemented by teachers in a classroom setting with all students for the purposes of teaching good behavioral patterns, thus preventing and reducing inappropriate behavior (Tyjian, 2014). These procedures are considered universal because they are implemented with the entire class rather than with individual children or small groups requiring additional behavioral support. Teachers who use effective classroom management can expect to experience improvements in student behavior and improvements that establish the context for effective instructional practices to occur.

Effective classroom management focuses on preventive rather than reactive procedures and establishes a positive classroom environment in which the teacher focuses on students who behave appropriately (Lewis \& Sugai, 2014). Rules and routines are powerful preventative components to classroom organization and management plans because they establish the behavioral context of the classroom by specifying what is expected, 
what will be reinforced, and what will be expected if inappropriate behavior occurs (Sugai, 2013). This prevents problem behavior by giving students specific, appropriate behaviors to engage in. Monitoring student behavior allows the teacher to acknowledge students who are engaging in appropriate behavior and prevent misbehavior from escalating.

A clear understanding of the effectiveness of classroom management as a package of practices is necessary to establish teachers' sustained classroom management and effectiveness. A teacher's ability to make efficient use of lesson time, to coordinate classroom resources and space, and to manage students' behaviour with clear rules that are consistently enforced, are all relevant to maximizing the learning that can take place. These environmental factors are necessary for good learning to take place.

\section{Statement of the Problem}

It seems intuitive and obvious that teachers cannot help children learn things they themselves do not understand. How teaching leads to learning is undoubtedly very complex. The majority of classroom teachers lack substantial subject matter knowledge, the knowledge of what to teach, and how to teach the subject matter effectively (Chonjo, 2010; Sichizya, 2013). Because of poor teaching skills by teachers, secondary school students are underachieving or not performing well in English Language as a subject in public examinations (Peters, 2016). Teachers' abilities to make efficient use of lesson time, coordinate classroom resources and space, manage students' behaviour with clear rules that are consistently enforced has also been found to be lacking among many teachers. Specifically, most teachers of English Language lack classroom management skill, lesson delivery skill, lesson planning skill and lesson evaluation skill. These are all relevant to maximizing the learning that can take place.
These factors are necessary hygiene factors to allow learning, rather than direct components of it. This study therefore seeks to find out the effect of teachers' teaching skills and students' learning of English language in public secondary schools in Oruk Anam Local Government Area of Akwa Ibom State.

\section{Purpose of the Study}

The main purpose of this study is to find out the effect of teachers' pedagogical skills on students' learning of English language in public secondary schools in Oruk Anam Local Government Area of Akwa Ibom State. Specifically, the study sought to:

1. Investigate the relationship between teachers' classroom management competence and students' learning of the English language.

2. Ascertain the relationship between teachers' lesson delivery skills and students' learning of the English language.

3. Determine the relationship between teachers' level of communication and students' learning of the English language.

\section{Research Questions}

The following research questions were framed to guide the study:

1) What is the relationship between teachers' classroom management competence and students' learning of English language?

2) What is the relationship between teachers'lesson delivery skills and students' learning of English language?

3) What is the relationship between teachers' level of communication and students' learning of English language?

\section{Research Hypotheses}

The following null hypotheses were formulated for the study:

$\mathrm{H}_{01}$ : There is no significant relationship between teachers' classroom management 
competence and students' learning of English language.

$\mathrm{H}_{02}$ : There is no significant relationship between teachers' lesson delivery skills and students' learning of English language.

$\mathrm{H}_{03}$ : There is no significant relationship between teachers' level of communication and students' learning of English language.

\section{REVIEW OF RELATED LITERATURE}

\section{Theoretical Framework}

Theories provide foundation for claims; introduce ideas and explanations for phenomena. They also provide framework needed within which behavior can be interpreted (Hallam, 2014). The related theories on which the study on teachers' teaching skills and students' learning of English Language in public secondary schools in Oruk Anam Local Government Area will be conducted are: Behaviorist Learning Theory, Constructivist Learning Theory and Social Constructivist Learning Theory.

\section{Behaviorist Learning Theory}

Behaviourism emerged as a theory of learning from the work of Thorndike (1911), Pavlov (1927) and Skinner (1957), becoming dominant in the 1960s and 1970s. The scientifically proved laws of stimulus-response and classical and operant conditioning were used to explain the learning process through the use of rewards and sanctions or trial and error. This was seen as biologically driven, a form of adaptation to the environment. The learner is rewarded for small steps of learning and achievement with consistent positive reinforcement. Broadly speaking, behaviourism supports teacher-controlled or centred approaches where the teacher is the sole authority figure (Muijs \& Reynolds, 2011; Zeegers, 2012). Knowledge is parceled out from different parts of a separated curriculum that children experience as distinct subjects, and directed from the teacher to the students in set sequences, with little student choice or interaction. Assessment is often examoriented and high stake, without teachers' direct involvement.

According to Sumra (2011), pedagogic approaches that can broadly be described as behaviouristic in origin may result in practices such as lecturing, demonstration, rote learning, memorisation, choral repetition, imitation/copying or 'master-classes' (e.g. learning music or dance). Structured or direct/explicit instruction as a practice differs in being teacher-led rather than teacher- centred, and indicates that teachers follow a particular sequence, often scripted and even prescriptive, as in the teaching of early reading, but this may develop into more studentcentred activities at a later stage of the lesson (Barratt, 2013). Behaviourism could be held to be universal as a theory, applicable within a variety of contexts, both cost- and time-efficient and require fewer resources, including demanding lessqualified and -skilled teachers. Critiques of behaviourism lie in the surface-nature of the knowledge acquired and the way in which the 'one-size-fits-all' approach excludes students with individual differences, or where the teacher remains unaware of students' current knowledge or misconceptions, or where the use of sanctions such as corporal punishment as a deterrent is acceptable (Brown, 2013).

Instructional practices associated with this theory include: educators reinforce appropriate behaviour through rewards ranging from a positive statement to tangible rewards such as star charts; educators avoid reinforcing inappropriate behaviour or remove children who are behaving inappropriately; educators draw children's attention to the consequences of their behaviour (Etuk, 2014). 


\section{Constructivist Learning Theory}

Based especially on the work of Piaget (1980), constructivism differs from behaviourism in theorising the mind as inherently structured to develop concepts and acquire language. Individual learners actively explore their environment by building on their existing cognitive structures or schemas. When these schemas are adequate to deal with a new object, situation or problem, learning occurs through a process of assimilation. When an existing schema is not adequate to deal with a new object, situation or problem, a process of accommodation is required whereby learners modify their existing schema (Carney, 2010).

Constructivist approaches see that activities are provided to build on children's current knowledge and match their appropriate developmental stage, and challenge them so that through the process of accommodation, they continue to make progress. Individual and group work centred on problem solving and project work is appropriate (Alexander, 2012). Concrete activities are privileged for younger children, with activities involving symbolic and abstract thought reserved for older students. While the terms 'student - or learner-centred' pedagogies are sometimes used interchangeably with childcentred education (CCE), the latter has a different and longer history. In child-centred education, as developed by Locke, Rousseau and Froebel from the late 1600s onwards, pleasure, interest and playfulness are seen as central to the child within an integrated curriculum in which the children commune freely with nature and have some agency over their own learning. Child-centred learning pedagogies can be theorised as influenced by constructivism (Tanner, 2013). However, critiques of child-centred education suggest that it is context-specific rather than universal, and possibly elitist in its outcomes.

According to Brown (2013), pedagogical practices associated with this theory include: educators facilitate children's learning by planning a rich environment with routines and play-based experiences that may be linked to learning goals appropriate for children's unique and holistic development; using developmental theory, educators observe children to understand and interpret their development and individual differences.

\section{Social Constructivism}

Social constructivism sees knowledge as socially constructed and learning as essentially a social process. It is mediated through cultural tools, above all by language, which needs to be the learner's first language or at least one very familiar to them, and facilitated by drawing on examples or contexts familiar to the learners so that meaning making is prioritized (Rogan, 2016). Teachers apply this model by setting up a 'Zone of Proximal Development' (ZPD), that is, an area of activity where, with the aid of a teacher or more knowledgeable peers, students are able to do what they cannot achieve alone (O'Sullivan, 2014). Learning involves students gradually internalising this social activity with higher order cognitive development or thinking directly developed and structured by their external social speech. Children's natural or 'spontaneous' concepts meet with and are further developed by the scientific or more abstract concepts they are taught in school or by an adult through guided instruction (Moon, 2012; Ono \& Ferreira, 2013). Such scaffolding or guided support requires a skillful mix of teacher demonstration, praise, minimization of error, practice and direct instruction (Moon, 2007).

According to Mukhopadhyay and Moswela (2010), pedagogic practices consistent with social constructivist approaches prioritise student-teacher or student-student interaction. Small-group, pair and whole-class interactive work, extended dialogue with individuals, higher order questioning, teacher modelling, showing, reciprocal teaching and co-operative learning can all be seen as justified by social constructivism. To 
this extent, social constructivism could be seen as supporting student- or learner-centred pedagogy, although social constructivism would suggest a much stronger role for the teacher than would be suggested by student- or learner-centred. Assumptions around student-centred pedagogy are that teachers share their students' language and culture, accept a more democratic and less authoritative role, and know how to set up effective group work and tasks and to offer skillful supported instruction at the point it is needed. Furthermore, space is needed for flexible social groupings, and within this, students need to feel that they have the right to talk and contribute to their peers' learning (Qhobela, 2012). Inherent within this is recognition of the student as a person with rights, with its human rights-based approach to schools and pedagogy (Brown, 2013).

\section{CONCEPTUAL FRAMEWORK EMPIRICAL STUDIES}

\section{Teaching and Teaching' Skills}

The primary purpose of teaching at any level of education is to bring a fundamental change in the learner (Tebabal \& Kahssay, 2011). To facilitate the process of knowledge transmission, teachers should apply appropriate teaching methods that best suit specific objectives and level exit outcomes. Pedagogy is an encompassing term concerned with what a teacher does to influence learning in others. This involves activities that evoke changes in the learner. According to Bernstein (2012), teaching skills is a sustained process whereby somebody acquires new forms or develops existing forms of conduct, knowledge, practice and criteria from somebody or something deemed to be an appropriate provider and evaluator. Alexander (2011) posited that teaching is an act while pedagogy is both an act and a discourse. Pedagogy comprises teachers' ideas, beliefs, attitudes, knowledge and understanding about the curriculum, the teaching and learning process and their students, and which impact on their teaching practices. That is, what teachers actually think, do and say in the classroom constitutes pedagogy (Udo, 2014). Teachers' thinking and ideas are manifested in their overall pedagogic approaches, garnered from the kinds of teaching and learning experienced as school students themselves, the approaches promoted in initial teacher education and continuing professional development, those specified in the current school curriculum and those pervasive in colleagues' classrooms.

Pedagogy is a term that is used in education in a variety of ways. To some, it can appear to be a "buzz word," or a form of jargon, designed to make talk of teaching appear more sophisticated and remote from real world practice. In many instances it is often used as a synonym for teaching (Brown, 2013). However, using pedagogy in that way weakens the real meaning of the term. Pedagogy has more to do with understanding the relationship between teaching and learning in ways that foster children's development and growth. Van Manen (2014) described pedagogy as a practice, relational values, the personal engagement, the pedagogical climate, the total life-worlds and especially the normativity of life with children at school, at home, and in the community. Therefore, in considering carefully what developing pedagogy might mean for teachers, it becomes immediately apparent that it entails considerably more than accumulating a bag of teaching tricks (Oton, 2013). Although there is clearly a need for teachers to be familiar with, and capable of using a range of teaching procedures, it is equally important that their use alone is not seen as an end unto itself. Hence, in developing their pedagogy, teachers are working as professionals to better understand, create and respond to the appropriate conditions through which educational practice might be enhanced and through which their 
professional knowledge might grow (Alexander, 2011).

Pedagogy is the practice of teaching framed and informed by a shared and structured body of knowledge. This knowledge comprises experience, evidence, understanding moral purpose and shared transparent values (Gilden \& Bell, 2012). It is by virtue of progressively acquiring such knowledge and mastering the expertise through initial training, continuing development, reflection and classroom inquiry and regulated practice that teachers are entitled to be treated as professionals (Alexander, 2011). Watkins and Mortimore (2013) defined pedagogy as any conscious activity by one person designed to enhance the learning of another. The role of teachers as architects implies a broad and carefully considered set of approaches designed to meet a wide range of contexts and individual needs.

Pedagogy is the instructional techniques and strategies that allow learning to take place. It refers to the interactive process between teacher/practitioner and learner and it is also applied to include the provision of some aspects of the learning environment (including the concrete learning environment, and the actions of the family and community) (Gilden \& Bell, 2012). It is about learning, teaching and development influenced by the cultural, social and political values the teacher has for the children and is underpinned by a strong theoretical and practical base (Farquhar, 2013).

Gage (2015) defined pedagogy as the science of the art of teaching. This is a science that is continually developed by innovative teachers and the academic researchers who study their practice. It is in this way that many pedagogic strategies have become accepted as established (and practiced) knowledge. Pedagogy is the instructional techniques and strategies which enable learning to take place. It refers to the interactive process between teacher/practitioner and learner, and it is also applied to include the provision of some aspects of the learning environment (including the concrete learning environment, and the actions of the family and community) (Blatchford, 2012). Pedagogy develops from a range of factors including theories and research evidence, political drivers, evidence from practice, individual and group reflection, educators' experiences and expertise, and community expectations and requirements. It informs both curriculum (all the interactions, experiences, activities, routines and events planned and unplanned) and teaching in a service. It reflects and supports the principles of and outcomes sought by a service (Gage, 2015).

The ultimate goal of any teaching is to develop student learning. Effective pedagogy are those teaching and learning activities which make some observable change in students, leading to greater engagement and understanding and/or a measureable impact on student learning. Effective pedagogy not only produces outcome results in relation to input, but also represents a common core of values and objectives to which all those involved can subscribe. (Moyles, Adams \& Musgrove, 2012)

Effective teaching is defined as pedagogical practices that facilitate for diverse children their access to knowledge, activities and opportunities to advance their skills in ways that build on previous learning, assist in learning how to learn and provide a strong foundation for further learning in relation to the goals of the early curriculum. In all of this, a concern for students and their learning is at the heart of the endeavour. Viewed from this perspective, telling is not teaching and listening is not learning. Rather, the fluency with which teachers adopt, adapt and adjust practices to create conditions for learning matters in creating strong and meaningful links between teaching and learning that highlight the real meaning of an effective pedagogy (Mills, 2014). Pedagogic expertise can be thought of as a combination of science, craft and art. This notion 
helps in understanding the complementary needs for collectively created knowledge, professional skills and personal capacities. Effective teachers must have an awareness of this body of knowledge, but they must also be considered to be practising artists in selecting the most appropriate strategies to apply in any given learning and teaching context (Gilden \& Bell, 2012). The best teachers creatively draw upon their knowledge of the interests and capabilities of the children in their care, and also upon a wide range of material, cultural and intellectual resources to provide the children with the most effective, engaging, memorable and rewarding learning experiences possible on a day-to-day basis. And, just as a kind of scientific 'development' may be seen in the work of many great painters, the performance of effective teachers also develops as they continually reflect upon, hypothesize about, critically evaluate and moderate their practice to achieve excellence. So much is predicated on the teachers' contextual literacy of the needs and backgrounds of their students.

To promote order and learning in the classroom, every teacher should possess essential teaching skills. No one can teach something to someone without doing it in some particular way, and that way of teaching has significant effects on the entire teaching and learning situation. Ehindero and Ajibade (2000) posit that: teaching is a process of continuous personal development and professional self-discovery alongside an emerging understanding of the teaching and learning process.

\section{Teachers' Classroom Management Competence and Teaching Skills}

Classroom management is the process by which teachers and schools create and maintain appropriate behavior of students in classroom settings. The purpose of implementing classroom management strategies is to enhance positive social behavior and increase student academic engagement (Emmer \& Sabornie, 2015; Everston \& Weinstein, 2016). Classroom management has been defined broadly as any action a teacher takes to create an environment that supports and facilitates both academic and social-emotional learning. Instructional procedures could also be considered classroom management by this definition; however, effective instruction alone is insufficient for establishing universal classroom management. Procedures that structure the classroom environment, encourage appropriate behavior, and reduce the occurrence of inappropriate behavior are necessary for strong classroom management (Evertson \& Clements, 2013). Instructional procedures, although equally important to the classroom environment, can be considered a separate set of procedures.

The components of effective classroom management are important in several ways. Focusing on preventive rather than reactive procedures establishes a positive classroom environment in which the teacher focuses on students who appropriately behave (Lewis \& Sugai, 2014). Rules and routines are powerful preventative components to classroom organization and management plans because they establish a behavioral context for the classroom that includes what is expected, what will be reinforced, and what will be re-taught if inappropriate behavior occurs. This prevents problem behavior by giving students specific, appropriate behaviors to engage in. Monitoring student behavior allows the teacher to acknowledge students who are engaging in appropriate behavior and prevent misbehavior from escalating (Colvin, 2013).

Classroom management is the major prerequisite to effective instruction (Weber, 1986). It entails a series of activities by which the teacher establishes and maintains those classroom conditions that facilitate effective and efficient teaching and learning. It is a skill that guides teachers to use and develop behavioural classroom 
protocols, including arriving in and exiting classroom. Shawer (2010) also reports that classroom management includes classroom organizing strategies such as seating arrangements, learning styles and positive student-teacher relationships. Oladiran (2004) includes teaching posture as one of the classroom management strategies. According to him, a teacher is to stand at the edge of the chalkboard, facing the class and backing the wall. If a teacher is talking and writing at the same time, he ends up instructing the wall and there is tendency that little or no learning will take place.

Classroom organization and management program is a professional development series developed to create effective learning environments. The main components of Classroom Organization and Management Program are: (1) organizing the classroom; (2) planning and teaching rules and procedures; (3) managing student work and improving student accountability; (4) maintaining good student behavior; (5) planning and organizing; (6) conducting instruction and maintaining momentum; and (7) getting the year off to a good start. For the purpose of this review, universal or whole-class classroom management is defined only as: a collection of non-instructional classroom procedures implemented by teachers in classroom settings with all students for the purposes of teaching pro-social behavior as well as preventing and reducing inappropriate behavior. This definition includes packaged interventions with multiple components (e.g., rules, classroom procedures, reinforcement, consequences) used as a comprehensive approach to universal classroom management. It also includes group contingencies such as the "Good Behavior Game" when used as a universal approach for classroom management.

\section{Teachers' Lesson Delivery and Teaching Skills}

The primary purpose of teaching at any level of education is to bring a fundamental change in the learner (Tebabal \& Kahssay, 2011). To facilitate the process of knowledge transmission, teachers should apply appropriate teaching methods that best suit specific objectives and level exit outcomes. In the traditional epoch, many teaching practitioners widely applied teacher-centered methods to impart knowledge to learners comparative to student-centered methods.

Delivery skills are important in any teaching method a teacher intends to use. As a lesson with excellent content can easily be ruined by poor delivery skills, so also varieties of methods no matter how good those methods may be, can also be ruined without the use of good delivery skills. There are certain skills that a teacher needs to know, learn, practice and skillfully apply when teaching in order to teach professionally, effectively, and achieve desired results for himself or herself and the learners. In other words, any prospective teacher ought to be interested in mastering different delivery skills needed to become an effective teacher. Shostak (2006) is of the view that when teachers skillfully vary their teaching skills, there is tendency of strong positive effect on students ${ }^{\text {ee }}$ learning and a teacher who continue to teach on and on in the same monotonous skills inevitably has a dulling effect on most learners.

Therefore, teachers need to be interested in acquiring different delivery skills that will enable them achieve desired results and retain those skills.In order to be an effective teacher, one must be an effective questioner (Sadker \& Sadker, 2016). Questions must create different levels of thinking. A skillful teacher should be able to formulate questions based on the six levels of Bloom's Taxonomy in order to encourage learners to engage in a variety of cognitive processes.

\section{Teachers' Level of Communication and Teaching Skills}


The procedure of communication is a dynamic concept and not a stationary. Communication is a skill and it could be acquired through proper training. It takes presence of mind and courage to face people with the power to prove what they want to convey through communication. A communication can be said successful only if we are able to convince people for whatever we wanted to convey (Akpan, 2013). Depending on the environment and circumstances, effectiveness of communication skills is affected by many variables. It is a basic social process required for the growth and development of individuals, groups, society and people. Knowing good communication skills are really important in every walk of life, especially in teaching English language. To make class room teaching effective, the teacher should acquire the different communication skills to be able to pass the message across to the students without ambiguity (Lorentz, 2009).

If there is an art essential to good teaching, it is that of communication. It is very important because teaching cannot occur without the use of oral or sign language communication. It implies that teachers should monitor their own speech to ensure that their presentation is as clear and logical as possible. Eggen and Kauchack (2001) highlighted four aspects of effective communication that are highly essential for learning and motivation. They are; precise terminology, connected discourse, transition signals and emphasis. Skillful teachers summarize and link ideas together at the end of their lesson, review summaries of previous work and help students link what has been learnt to what is coming. Essential teaching skills and teaching methods are like two sides of the same coin. Skills are the required characteristics or ingredients for effective teaching while methods can be compared to pattern to be followed in teaching.

Teachers are encouraged to develop a strategy of encouraging learners to take a more active role in their own learning. Communicative approach to language teaching and learning advocates the teaching and learning of second languages to enable learners to communicate with other speakers of the second language (Brown \& Rodgers, 2002). Since the early 1970's, language teaching methodology has been largely concerned with developing communicative competence, that is, knowing what to say, to whom, and how to say it, and communication strategies (Savignon, 2007). Theoretical and empirical investigations in the field of communicative language teaching resulted in the development of several models of communicative competence (Canale, 2013; Bachman, 2015), which are currently used worldwide.

The main principle underlying communicative language teaching is the notion of "communicative competence" which was originally defined by Hymes (1972) as the aspect of a person's language competence that enables him to convey and interpret messages as well as to negotiate meanings interpersonally within specific contexts.

Teachers of a second language (L2) teach the target language more effectively through teaching and participating in meaningful classroom communication with students. This concept of language learning explains the emergence ofCommunicative Approaches to L2 teaching over the last decades, whose pedagogical goal is to develop learners' communicative competence, i.e., the ability to use the linguistic system in an effective and appropriate way.Classroom communication includes face-toface interactions and the communications necessary between the participants involved in the classroom to ensure that learning takes place (Kogut \& Silver, 2009).

As Briscoe, Arriaza, and Henze (2009) suggest, it is within these face-to-face interactions that teachers use language to "communicate expectations of students, faculty, and parents; to 
discuss policies, praise people, propose changes in curriculum, indicate that they are listening, carry out disciplinary action, and for a host of other actions"(p. 16).

That is one of the ways why classroom communication differs from normal communication in the community. The main purpose of communication in a classroom is to instruct and inform. In addition, communication in a classroom setting is unique because it has highly regulated patterns of communication between teachers and students, both of whom have a different status. The higher status of the teacher allows him or her to conduct the class from beginning to end; he or she can choose the topic, decide how to divide the topic into smaller units, control who talks, and when and where they do so. Teachers, whether consciously or not, communicate (usually by using language) in order to orchestrate learning events in their classroom.

According to Farrell (2009), teachers use communication in the classrooms in order to accomplish three things: to elicit relevant knowledge from students, to respond to things that students say and to describe the classroom experiences that they share with students. It is hoped that by looking at the classroom communication, teachers' communication skills will be identified and teachers will become more aware of their communication skills and communication patterns that currently exist in their classrooms and will be able to evaluate whether these patterns provide opportunities for their students to learn. By focusing on more than one features of communication skills that they use when teaching, teachers would be able to practice and monitor their use of communication skills not only as essential input for their students but also to achieve more effective teaching when conducting a lesson. This implies that for effective teaching to occur, the teacher must be skilled in several features of communication skills, including gaining students' attentions; giving instructions, managing errors; explaining; teachers' language; and nonverbal communication skills were explored.

\section{The Concept of Teaching English Language}

The fact that young students learn their first language with such speed and competence must mean that if the process can be better understood it should be possible to design experiences through which students learn a second language in much the same way as they learn their first language (Adams, 2014).

Concerning learning a foreign language like English language, research has shown that there are obvious similar steps that must be followed as with acquiring the mother tongue (Tough, 2013). Therefore, it is important to support communication through the use of gesture, facial expression and action because this gives students clues to the meaning of what they hear and so draws their attention to and helps them to become familiar with the sounds, rhythms and stress of the second language which are different from those of their first language. This suggests that teachers of English language have to be more detailed and adopt strategies that will make their students understand the language easily.

\section{Teaching Strategies}

Teachers can help their students in learning the language easily through the following processes.

Imitation: Imitation is used when trying to produce speech by imitating single words that are used by others. When the meaning of words is attached, students start to use them frequently and repeat them in terms of practice. This aids easy articulation of the words.

Repetition: When students respond to a teachers' comment by repeating what has been said, this helps in remembering the patterns of the words 
before going on to formulate a response. This also helps students to recognize the structure of the utterances.

Formulaic Speech: This stage is reached when students learn and continuously use short phrases that are attached to certain everyday life situations. Recent studies of young students learning a second language have confirmed that imitation, repetition and formulaic speech are the first strategies to be used. In summarizing evidence on second language learning, Hatch (2013) places importance on such use, not only for students' first steps in learning the second language, but for their continuing progress (Tough 2013).

Incorporation: The final stage of the teaching/learning strategy is incorporationwhich is based on "taking the form of repeating a word or short phrase used by the teacher and putting it in some sequence with elements already established" (Udo, 2012). This leads towards recognizing principles of the language use.

\section{Review of Related Empirical Studies}

The study is related to the present study in that it considered an aspect of teaching skills (lesson planning skills). It was however different from the present study in that it did not look at other teaching skills such as communication skills, evaluation skills, classroom management skills and so on.

Shehu (2011) examined the effect of classroom management in selected Secondary Schools in Ikot Abasi Local Government Area of Akwa Ibom State. The study consisted 364 teachers of Secondary Schools in Ikot Abasi Zone. It used frequency counts and percentages to analyze the data. No hypotheses were tested. However, the study found out that good classroom management increases the overall performance of the students. The author therefore recommended that good classroom management should be encouraged as it aids teaching-learning. He also recommended that teachers should be trained and retrained through workshops, Seminars and Conferences for the purpose of skill acquisition necessary for the management of the classroom. The study is related to the present study since it examined classroom management skills. However, it differed in that it was only concerned with only one variable of the study.

Abdulahi (2010) examined lesson delivery skills among Secondary Schools teachers. The study sampled 240 teachers in Kaduna State and questionnaire was administered to all of them. Observation schedule was used to observe 48 teachers at work. Data were analyzed descriptively using percentages. Major findings were that some teachers do not plan their lessons and most of those who plan write one plan for three to five lessons a week. Lesson delivery was poorly done by all categories of teachers. He observed that most teachers had no serious commitment to lesson planning. Some of them drew lesson plans only when they were aware that school inspectors were to visit the school. Many Secondary Schools teachers omitted essential elements of the lesson plan such as date, time, duration, instructional resources, stated objectives that had focus, previous knowledge and so on. He also observed that many teachers manifested poor delivery skills by not making use of appropriate teaching methods. He therefore recommended that there should be a rethink on the abolition of the Grade II teachers' certificate and the basic training that was thrown away with the programme. Orientation programmes on various teacher practices could be arranged for new entrants. Above all, there should be a rethink on the caliber of people admitted into teaching profession and continuous professional training for teachers should be made mandatory so as to update their skills. This study is similar to the present study since it was concerned with lesson planning and delivery skills. The study differed in 
that it focused entirely on teachers and not on Students' performance.

Olatidoye (1994) studied Teachers' communication skills and learning of English language in Osun State Secondary Schools. The study sampled two hundred (200) English language students and fifty (50) English language teachers. Table of frequency and percentages were used to analyze the data while t-tests were used to test the hypotheses. The study revealed that teachers with good communication skills impact more on the students than those with poor communication skills. He also recommended that curriculum developers and evaluators need to review the curriculum periodically to meet the ever-increasing demands and changes in language usage of the contemporary society. His study relates to the present study since it examined teachers' communication skills. It was however, different in that this is only one of the variables considered in the present study.

\section{RESEARCH METHOD}

\section{Area of the Study}

Oruk Anam is a Local Government Area located in the southwestern part of Akwa Ibom State, Nigeria. It is one of the eight Annang-speaking local government areas of the state. It consists of two major political units, namely, the Oruk zone, and the Anam zone. Oruk zone used to be a Local Government Area with headquarters at Urua Anwa. Oruk zone was known as Southern Annang County Council of the former Abak Division. Anam zone used to be Anam Local Government Area with headquarters at Ikot Akpan Essien. Anam was called Anam or Annang County Council in the former Opobo Division. In 1989, the two Local Government Areas were merged into one. It shares the same boundary with IkotAbasi/Mkpat-Enin (Ibibio speakers) by the south/east and Ukanafun (Anaang speakers) by the west. Its population according to the 2006 census is about 172,000 with a growth rate of $2.5 \%$ per year. Its inhabitants are mostly farmers, craftmen and civil servants. The area is a major gateway to Port Harcourt and Aba as such there is lots of commercial activities along the major road points like Ekparakwa. The area hosts some government interest like the general hospital located in Ikot Okoro, police stations and schools. Some major towns include Ikot Ibritam, Ikot Akpan Essien, Ata Obio Akpa, Ikot Inuen, Ikot Afanga, Ibesit Okpokoro, and others.

\section{Research Design}

The study was carried out using a survey research design. (Ezeji, 2014) explained that through survey research design, researchers identify present conditions, prevailing needs as well as provide information on which to base sound decisions. Since the study involved a collection of opinions on teachers' teaching skills and students' learning of English Language among public secondary schools in Oruk Anam Local Government Area, survey design was considered appropriate.

\section{Population of the Study}

The population of the study will of all the teachers in the twelve public secondary schools in Oruk Anam Local Government Area of Akwa Ibom State. The total number is 685 (State Secondary Education Board, 2017).

\section{Sample and Sampling Technique}

A simple random sampling was used to select twenty percent of the population of the teachers to participate in the study. This gave a total sample size of 137 teachers who participated in the study.

\section{Instrument for Data Collection}

A structured questionnaire developed by the researchers and tagged 'Teachers' Pedagogical Skills and Students' Learning of English Language 
Questionnaire (TPSSLELQ)" was used for data collection. It will consisted of two sections; A and B. Section A was on the demographic information of the respondents. Section B had thirty items in all. Section B had a four point rating of Strongly Agree (SA), Agree (A), Disagree (D), and Strongly Disagree (SD).

\section{Validation of Instrument}

The instrument was validated by the colleagues before it was finally approved for administration to the study respondents. Items were validated for clarity, appropriateness of language usage, and ability to elicit accurate information in relation to the objectives of the study. Items in the questionnaire were examined and found to meet the intended attributes sought in the research questions.

\section{Reliability of Instrument}

To determine the reliability of the instrument an internal consistency of the items was done using a test-retest method. The instrument was distributed to 20 neutral teachers who were not members of the study at first attempt, and at second attempt after a period of two weeks. The two sets of scores were collated and compared for correlation coefficient. A Cronbach Alpha Co-efficient analysis was used in determining the level of reliability which was found to be $r=0.857$. The computation of the reliability coefficient is presented in table 3.1.

Table 3.1 Crobach's Alpha Reliability $(\mathbf{N}=\mathbf{2 0})$

\begin{tabular}{|l|c|c|c|c|}
\hline \multicolumn{1}{|c|}{ Variable } & Items & Mean & SD & Alpha \\
\hline Teachers' Classroom Management Skills & 5 & 13.60 & 2.76 & .841 \\
\hline Teachers' Lesson Delivery Skills & 5 & 12.39 & 2.71 & .802 \\
\hline Teachers' Level of Communication & 5 & 26.90 & 3.20 & .916 \\
\hline Concept of Teaching English Language & 5 & 18.84 & 2.35 & .810 \\
\hline
\end{tabular}

\section{Method of data Collection}

The questionnaires were administered to the respondents by the researchers with the assistance of a trained research assistant in each of the schools covered in the study. The questionnaire was accompanied with a letter introducing the researchers/research assistant and the purpose of the study. After completion of the questionnaires by the respondents, the researcher and the research assistant retrieved the completed questionnaires from the respondents.

\section{Method of data Analysis}

The statistical method that is used to analyze the data generated in the study is Pearson's Product Moment Correlation (PPMC). The research questions were analyzed using the mean and standard deviation while Person's Product Moment Correlation (PPMC) was used to test all the hypotheses at 0.05 level of significance 


\section{DATA ANALYSIS AND DISCUSSION OF FINDINGS}

\section{Research Question 1}

What is the relationship between teachers' classroom management competence and students' learning of English language?

Table 4.2: Nature of relationship between teachers' classroom management competence and students' learning of English language ( $N=130)$

\begin{tabular}{|l|c|c|c|}
\hline \multicolumn{1}{|c|}{ Variable } & Mean & S. D & r \\
\cline { 1 - 3 } Teachers' Classroom Management Competence & 21.71 & 7.45 & .309 \\
\cline { 1 - 3 } Students' Learning of English Language & 30.03 & 13.48 & \\
\hline
\end{tabular}

$\mathrm{r}$-crit $=.178$

Table 4.2 reveals that the calculated $\mathrm{r}$ value is .309 . This means that there is a positive relationship between teachers' classroom management competence and students' learning of English language. This implies teachers that are competent in classroom management will enhance higher academic achievement of the students than those who are not good at classroom management. Since the computed r-value is .309 , this shows that the relationship is positive.

\section{Research Question 2}

What is the relationship between teachers' lesson delivery skills and students' learning of English language?

Table 4.3: Nature of relationship between teachers' lesson delivery skills and students' learning of English language $(\mathrm{N}=130)$

\begin{tabular}{|l|c|c|c|}
\hline \multicolumn{1}{|c|}{ Variable } & Mean & S. D & r \\
\hline Teachers' Lesson Delivery Skills & 22.07 & 7.42 & \multirow{2}{*}{.277} \\
\cline { 1 - 3 } Students' Learning of English Language & 30.03 & 13.48 & \\
\hline
\end{tabular}

$\mathrm{r}$-crit $=.178$

Table 4.3 shows that the calculated $\mathrm{r}$ value is .277 . This means that there is a positive relationship between teachers' lesson delivery skills and students' learning of English language. This implies that teachers who have good lesson delivery skills will impact more on the students and thus leads to improved performance of the students. Since the computed r-value is .277, this shows that the relationship is positive.

\section{Research Question 3}

What is the relationship between teachers' level of communication and students' learning of English language? 
Table 4.4: Nature of relationship between teachers' level of communication and students' learning of English language $(\mathrm{N}=130)$

\begin{tabular}{|l|c|c|c|}
\hline \multicolumn{1}{|c|}{ Variable } & Mean & S. D & \multicolumn{1}{|c|}{ r } \\
\hline Teachers' Level of Communication & 21.69 & 7.84 & \multirow{2}{*}{.245} \\
\cline { 1 - 3 } Students' Learning of English Language & 30.03 & 13.48 & \\
\hline
\end{tabular}

$\mathrm{r}$-crit $=.178$

Table 4.4 shows that the calculated $r$ value is .245 . This means that there is a positive relationship between teachers' level of communication and students' learning of English language. This implies that teachers who are able to communicate effectively with their students will help them to learn with no difficulties. This will greatly enhance the students' performance. Since the computed r-value is .245 , this shows that the relationship is positive.

\section{Analysis of the Null Hypotheses}

Hypothesis (1): There is no significant relationship between teachers' classroom management competence and students' learning of English language.

Table 4.5: Pearson Correlation of the nature of relationship between teachers' classroom management skill and students' learning of English language ( $N=130)$

\begin{tabular}{|l|l|c|c|}
\hline \multicolumn{1}{|c|}{ Variables } & \multicolumn{1}{c|}{$\begin{array}{c}\text { Teachers' } \\
\text { Classroom } \\
\text { Management Skill }\end{array}$} & $\begin{array}{c}\text { Students' Learning } \\
\text { of English Language }\end{array}$ \\
\hline Teachers' Classroom & Pearson Correlation & 1 & $.309^{* *}$ \\
Management Competence & Sig. (2-tailed) & 130 & .000 \\
& $\mathrm{~N}$ & $.309^{* *}$ & 130 \\
\hline Students' Learning of English & Pearson Correlation & .000 & 130 \\
& Sig. (2-tailed) & 130 & \\
\hline
\end{tabular}

** Correlation is significant at the 0.01 level (2-tailed)

Table 4.5 reveals that the calculated r-value of .309 is greater than the critical r-value of .178 at .05 alpha levels and 130 degree of freedom. The result is significant; therefore the null hypothesis that there is no significant relationship between teachers' classroom management competence and students' learning of English language is rejected and the alternate hypothesis is upheld. The result means that teachers' class room management competence has a significant influence on students' learning of English language. 
Hypothesis (2): There is no significant relationship between teachers' lesson delivery skill and students' learning of English language.

Table 4.6: Pearson Correlation of the nature of relationship between teachers' lesson delivery skill and students' learning of English language $(N=130)$

\begin{tabular}{|l|l|c|c|}
\hline \multicolumn{1}{|c|}{ Variables } & \multicolumn{1}{c|}{$\begin{array}{c}\text { Teachers' Lesson } \\
\text { Delivery Skill }\end{array}$} & $\begin{array}{c}\text { Students' Learning of } \\
\text { English Language }\end{array}$ \\
\hline Teachers' Lesson & Pearson Correlation & 1 & $.277^{* *}$ \\
Delivery Skill & Sig. (2-tailed) & 130 & .001 \\
& $\mathrm{~N}$ & $.277^{* *}$ & 130 \\
\hline Students' Learning of & Pearson Correlation & .001 & 1 \\
English Language & Sig. (2-tailed) & 130 & 130 \\
& $\mathrm{~N}$ & & \\
\hline
\end{tabular}

** Correlation is significant at the 0.01 level (2-tailed)

Table 4.6 reveals that the calculated r-value of .277 is greater than the critical r-value of .178 at .05 alpha levels and 130 degree of freedom. The result is significant; therefore the null hypothesis that there is no significant relationship between teachers' lesson delivery skill and students' learning of English language is rejected and the alternate hypothesis is upheld. The result means that teachers' lesson delivery skill has a significantly influence on students' learning of English language.

Hypothesis (3): There is no significant relationship between teachers' level of communication and students' learning of English language.

Table 4.7: Pearson Correlation of the nature of relationship between teachers' level of communication and students' learning of English Language ( $N=130)$

\begin{tabular}{|l|l|c|c|}
\hline \multicolumn{1}{|c|}{ Variables } & $\begin{array}{c}\text { Teachers' Level } \\
\text { of } \\
\text { Communication }\end{array}$ & $\begin{array}{c}\text { Students' Learning } \\
\text { of English } \\
\text { Language }\end{array}$ \\
\hline $\begin{array}{l}\text { Teachers' Level of } \\
\text { Communication }\end{array}$ & Pearson Correlation & 1 & $.245^{* *}$ \\
& Sig. (2-tailed) & 130 & .005 \\
& $\mathrm{~N}$ & $.245^{* *}$ & 130 \\
\hline Students' Learning of English & Pearson Correlation & .005 & 1 \\
Language & Sig. (2-tailed) & 130 & 130 \\
\hline
\end{tabular}

** Correlation is significant at the 0.01 level (2-tailed)

Table 4.7 reveals that the calculated r-value of .245 is greater than the critical r-value of .178 at .05 alpha levels and 130 degree of freedom. The result is significant; therefore the null hypothesis that there is no significant relationship between teachers' level of communication and students' learning of English language is rejected and the alternate hypothesis is upheld. The result means that teachers' level of communication has a significant influence on students' learning of English language. 


\section{DISCUSSION}

Teachers' Classroom Management Competence and Students' Learning of English Language

The null hypothesis formulated in the study stated that there is no significant relationship between teachers' classroom management competence and students' learning of English language. Table 4.5 showed a calculated r-value of .309 which is greater than the critical r-value of .178 at .05 alpha levels and 130 degree of freedom. The result is significant; therefore the null hypothesis that there is no significant relationship between teachers' classroom management competence and students' learning of English language was rejected and the alternate hypothesis upheld. The result means that teachers' class room management competence has a significant influence on students' learning of English language. The findings of the study are in

consonance with the works of Shehu (2011), who found out that good classroom management increases the overall performance of the students.

This also aligns with Weber (1986) who stated that classroom management is a major pre-requisite to effective instruction.

\section{Teachers' Lesson Delivery Skills and Students' Learning of English Language}

The null hypothesis formulated in the study stated that there is no significant relationship between teachers' lesson delivery skills and students' learning of English language. Table 4.6 reveals that the calculated r-value of .277 is greater than the critical r-value of .178 at .05 alpha levels and 130 degree of freedom. The result is significant; therefore the null hypothesis that there is no significant relationship between teachers' lesson delivery skill and students' learning of English language is rejected and the alternate hypothesis is upheld. The result means that teachers' lesson delivery skill has a significantly influence on students' learning of English language. The findings of this study is in line with the findings of
Guga (2009) who found out that teachers who have good lesson delivery skills produce students who do better than those taught by teachers who do not have this essential skill. The study also aligns with the findings of Abdulahi (2010) who found out that lesson delivery skill is a skill that every teacher must have in order to deliver as a teacher.

Teachers' Level of Communication and Students' Learning of English Language

The null hypothesis formulated in the study stated that there is no significant relationship between teachers' level of communication and students' learning of English language. Table 4.7reveals that the calculated r-value of .245 is greater than the critical r-value of .178 at .05 alpha levels and 130 degree of freedom. The result is significant; therefore the null hypothesis that there is no significant relationship between teachers' level of communication and students' learning of English language is rejected and the alternate hypothesis is upheld. The result means that teachers' level of communication has a significant influence on students' learning of English language. This is in line with the findings of Olatidoye (1994) who showed that teachers with good communication skills impact more on the students than those with poor communication skills. The author added that to be an efficient teacher, one must learn to communicate the message of the lesson effectively to the learner.

\section{Summary of the Study}

Three variables were studied to show their influence on students' learning of English language in Oruk Anam local government area of Akwa Ibom State. Findings of the study showed that teachers' classroom management competence, teachers' lesson delivery skill and teachers' level of communication has a significant influence on students' learning of English language in Oruk 
Anam local government area of Akwa Ibom State, Nigeria.

\section{Conclusion}

On the basis of the research findings, the following conclusions were drawn:

1. That teachers' classroom management competence has a significant influence on students' learning of English language.

2. That teachers' lesson delivery skill has a significant influence on students' learning of English language.

3. That teachers' level of communication has a significant influence on students' learning of English language.

\section{Recommendations}

The study recommends the following:

1. Educational stakeholders should encourage good classroom management practices in the school as it aids the teaching-learning process. Teachers should be properly trained on effective classroom management skill.

2. Teachers should work on their lesson delivery skill as it has a significant influence on students' learning.

3. Teachers should learn good communication skills so that they will be able to pass on their lessons to the understanding of the students.

PRINCEWILL I. EGWUASI, Ph.D, Department of Curriculum Studies, Educational Management and Planning, University of Uyo, Uyo, Nigeria; NNENNA F. NNODI, Ph.D; ANIEFIOK S. UDOATAI, National Open University, Uyo Study Centre, Akwa Ibom State, Nigeria

\section{REFERENCES}

Abdulahi, T. (2010). Lesson delivery skills among secondary schools teachers. Communication Research Reports, 26, 146157.
Adams, G. N. (2014). Educating English Language Learners. NY: Cambridge University Press; p. 28.

Akpan, F. A. (2013). Learning style and learning spaces: enhancing experiential learning in higher education. Journal of the Academy of Management, Learning and Education, 4(2), 192-212.

Alexander, R. (2012). Peer observation of teaching: Perceptions of the observer and the observed. College Teaching, 55(1), 19-25.

Alexander, G. B. (2011). English language learners in U.S. schools: An overview of research findings. Journal of Education forStudents at Risk, 10(4), 363-385.

Arriaza, Y. \& Henze, S. (2009). Scaffolding for success: Beyond technology, questioning research and the information literate school community. Available at: http://www. fno.org/dec99/scafld.html. Accessed: February 21, 2016.

Bachman, A. C. (2015). Cognitive strategy instruction for adolescents: What we know about the promise, what we don't know about the potential. Harvard Educational Review, 78(1), 84-106.

Barratt, E. (2013). The power of feedback. Review of Educational Research, 77(1), 81-112.

Ben, K. G. (2013). Teacher Behavior and Student Achievement. New York: Macmillan, p. 47.

Bernstein, H. D. (2012). Psychology and Educational Practice. Berkeley, CA: McCutchan Publishers, pp. 387-407.

Blatchford, K. (2012). Methods and Instruction in Second Language Teaching. Abingdon, England: Routledge, pp. 681698.

Brown, F. (2013). Make it stick: The science of successful Learning. Harvard: University Press, p. 67.

Brown, P. \& Rodgers, A. C. (2002). Essays on pedagogy. London: Routledge, pp. 71-74.

Canale, T. D. (2013). Improving subject teaching: Lessons from research in science education. London, Routledge, p.521.

Carney, S. J. (2010). Attribution error and the quest for teacher quality. Educational Researcher, 39(8), 591-598.

Chonjo, K. (2010). The Impact of Attitudes and Aspirations on Educational Attainment and Participation. New York: University Press, p. 290. 
Colvin, M. (2013). Making science accessible to English learners: A guidebook for teachers Oxford: Longman, pp. 7786.

Eggen, R. \& Kauchack, M. F. (2001). Emotional Intelligence: Why it can matter more than IQ. New York: Bantam Books, p. 309.

Ehindero. S. \& Ajibade, M. G. (2000). The role of teaching trainees class management. Ife Journal of Theory and Research in Education, 8(2), 68 - 69.

Emmer, R. \& Sabornie, P. O. (2015). Inside the black box: Raising standards through classroom assessment. London: King's College, p.40.

Etuk, W. (2014). A union of insufficiencies: Strategies for teacher assessment in a period of educational reform. Educational Leadership, 46(3), 36-41.

Evertson, B. \& Clements, C. (2013). Development, experience and curriculum in primary education. London: Croom Helm, p. 129.

Everston, B. B. \& Weinstein, O. (2016). Developing literacy in second-language learners: A report of the national literacy panel on language-minority children and youth.Mahwah, $\mathrm{NJ}$ : Lawrence Erlbaum Associates, Inc., P. 47.

Ezeji, T. (2014). Learning style and learning spaces: enhancing experiential learning in higher education. Journal of the Academy of Management, Learning and Education, 4(2), 192212.

Farquhar, T. (2013). Teachers matter: Connecting work, lives and effectiveness. Maidenhead: Open University Press, P. 571.

Farrell, W. (2009). Threshold concepts within the disciplines. Rotterdam: Sense Publishers, pp. 70-72.

Florian, K. \& Rouse, T. D. (2011). Easy to dance to: Solving the problems of teacher evaluation with peer assistance and review. American Journal of Education, 113(3), 479-508.

Gage, B. D. (2015). Improving workplace learning. London: Routledge, p. 87.

Gilden, M. \& Bell, T. O. (2012). Developing the theory of formative assessment. Educational Assessment, Evaluation, and Accountability, 21(1), 5-31.
Hallam, R. I. (2014). Teacher fabrication as an impediment to professional learning and development: the external mentor antidote. Oxford Review of Education, 39(3), 345-365.

Hatch, D. K. (2013). Assessment accommodations for English language learners: Implications for policy based research. Review of Educational Research, 74, 1-28.

Haywood, G. (2014). Improving quality in education: Dynamic approaches to school improvement. Routledge: Taylor \& Francis Group, p. 21.

Hymes, M. (1972). Handbook of research in second language teaching and learning. Oxford: Longman, p. 18.

Kariminia, M. \& Salehizadeh, O. L. (2010). Methodological concerns about the education value-added assessment system. Educational Researcher, 37(2), 65-75.

Kizlik, B. (2010). An introduction to applied linguistics. London: Hodder Education, pp. 161-178.

Kogut, E, A. \& Silver, P. (2009). Academic Language for English Language Learners and Struggling Readers. Portsmouth, NH: Heinemann.

Lewis, N. \& Sugai, D. (2014). Measurement Issues and Assessment for Teaching Quality. Washington, DC: Sage Publications, p. 419.

Lorentz, B. (2009). Birth order and academic achievement. A seminar paper, department of educational foundations and counselling, Obafemi Awolowo University, Ile-Ife.

Mills, T. (2014). Higher education and the new professionalism of teachers: Realising the potential of partnership. A discussion paper. London, SCOP/CVCP.

Moon, K. (2007). The impact of individual teachers on student achievement: Evidence from panel data. The American Economic Review, 94(2), 247-252.

Moon, K. (2012). Equipping teachers: A protocol to guide and improve inquiry-based instruction. The Science Teacher, 76(4), $46-53$

Moyles, A. Adams, C \& Musgrove, J. O. (2012). Language learner strategies: 30 years of research and practice. Oxford: Oxford University Press.

Muijs, W. \& Reynolds, T. (2011). Teacher characteristics and student achievement gains: A review. Review of Educational Research, 73(1), 89-122. 
Mukhopadhyay, H. E. \& Moswela, T. (2010). The influence of teachers' knowledge on student learning in middle school physical science classrooms. American Educational Research Journal, 50(5), 1020-1049.

O'Sullivan, M. E. (2014). The sensitivity of value-added teacher effect estimates to different mathematics achievement measures. Journal of Educational Measurement, 44(1), 47-67.

Oladiran, S. (2004). Cognitive Psychology for Teachers. New York: Macmilan.

Olatidoye. O. C. (1994). Teachers' communication skills and learning of English language in Osun State Secondary Schools. International Journal of Academic Research in Progressive Education and Development, 1(4), 1-16.

Ono, S. A. \& Ferreira, Q. (2013). Different tests, different answers: The stability of teacher value-added estimates across outcome measures. American Educational Research Journal, 48(1), 163-193.

Oton, C. D. (2013). Tracking and high school English learners: Limiting opportunity to learn. American Educational Research Journal, 42(2), 305-328.

Pavlov, T. F. (1927). Learning style inventory: Technical manual. Boston, MA: McBer and Company.

Peter, B. D. (2012). Talking, listening, and teaching: A guide to classroom communication. Canada: Corwin, p. 67.

Piaget, J. (1980). Behavioural Learning. New York: University Press.

Qhobela, S. (2012). Do we know a successful teacher when we see one? Experiments in the identification of effective teachers. Journal of Teacher Education, 62(4), 367-382.

Rogan, H. W. (2016). Teacher behaviour and student outcomes: Suggestions for research on teacher training and professional development. Teaching and Teacher Education, 25, $12-23$.

Sadker, M. E. \& Sadker, I. (2016). Questioning skills. In: Cooper, J. M. (Ed). Classroom Teaching Skills ( $3^{\text {rd }}$ Ed). Canada: D.C. Heath and Company, p.24.

Savignon, U. (2007). How the world's best-performing school systems come out on top. London, McKinsey \& Company, pp. 402-406.
State Secondary Education Board (2017). Akwa ibom state secondary board distribution of teachers in public schools. Uyo: Government Press, p. 182.

Shehu, G. D. (2011). Effect of classroom management in selected secondary schools in Ikot Abasi local government area of Akwa Ibom State. Journal of Language Learning, 4(2), 67-78.

Shostak, D. H. (2006). Lesson presentation skills. In: J.M. Cooper (Ed) Classroom Teaching Skills. (3 ${ }^{\text {rd }}$ Ed) Canada: D.C. Heath and Company, p.113

Sichizya, Q. Y. (2013). Effects of teachers' mathematical knowledge for teaching on student achievement. American Educational Research Journal, 42(2), 371-406.

Shawer, E. D. (2010). The Input Hypothesis: Issues and Implications. Harlow, England: Longman, p. 38.

Skinner, G. (1957). The Process of Education. Cambridge: Cambridge University Press.

Sugai, W. A. (2013). Approaches to evaluating teacher effectiveness: A research synthesis. Educational Research Journal, 48(3), 794-831.

Sumra, T. D. (2011). Improving students' learning with effective learning techniques: Promising directions from cognitive and educational psychology. Psychological Science in the Public Interest, 14(1), 4-58.

Tanner, K. (2013). Teacher effects and teacher effectiveness: A validity investigation of the Tennessee value added assessment system. Educational Evaluation and Policy Analysis, 25, 287-298.

Tebabal, E. \& Kahssay, H. A. (2011). Practical guidelines for the education of English language learners: Research-based recommendations for instruction and academic interventions. Portsmouth, $\mathrm{NH}$ : Center on Instruction.

Thorndike, N. M. (1911). Toward an applied theory of experiential learning: Theories of group process. London, UK: Wiley.

Tough, H. S. (2013). Social organizational factors in learning to read: The balance of rights hypothesis. Reading Research Quarterly, 17, 115-152.

Tyjian, T. (2014). Teachers' thinking about information and communications technology and learning: Beliefs and outcomes. Teacher Development, 5(2), 191-210. 
Udo, A. A. (2014). Self-regulation empowerment program: A school-based program to enhance self-regulated and selfmotivated cycles of student learning. Psychology in the Schools, 41(5), 537-550.

Van Manen, R. (2014). Implementing the cognitive academic language learning approach: Bilingual Research Journal, 19(3\&4), 379-394.

Watkins, B. N. \& Mortimore, E. (2013). The critical role of vocabulary development for English language learners. Learning Disabilities Research \& Practice, 20(1), 50-57.
Weber, A. (1986). A validity argument approach to evaluating teacher value-added scores. American Educational Research Journal, 48(3), 794-831.

Zeegers, L. (2012). Stability over time of different methods of estimating school performance. School Effectiveness and School Improvement, 25, 65-82. 